\title{
Ankara İlinde Ekmekte Tüketici Tercihleri
}

\author{
${ }^{*}$ Rahmi TAŞCl ${ }^{1} \quad$ Sevinç KARABAK ${ }^{1} \quad$ Merve BOLAT $^{1} \quad$ Oğuz ACAR ${ }^{1}$ \\ Turgay ŞANAL ${ }^{1} \quad$ Aliye PEHLIVAN $^{1} \quad$ Seda KÜLEN $^{1}$ \\ Erdoğan GÜNEŞ ${ }^{2}$ Mevhibe ALBAYRAK²
}

${ }^{1}$ Tarla Bitkileri Merkez Araştırma Enstitüsü Müdülüğü, Ankara

${ }^{2}$ Ankara Üniversitesi, Ziraat Fakültesi, Tarım Ekonomisi Bölümü, Ankara

*Sorumlu yazar e-posta (Corresponding author e-mail): rahmi.tasci@tarim.gov.tr

Geliş Tarihi (Received): 22.03.2017

Kabul Tarihi (Accepted): 12.05.2017

Öz

Bu çalışma; Ankara ilinde tüketicilerin ekmek tercihlerine etki eden faktörlerin belirlenmesi amacıyla gerçekleştirilmiştir. Çalışmada ankete katılacak ekmek tüketici sayısı basit tesadüfi örnekleme yoluyla belirlenmiş ve anketler 2015 yılında gerçekleştirilmiştir. Araştırma sonucunda, Ankara ilinde hane başına günlük 2.4 adet $(600 \mathrm{~g})$, kişi başına 1.4 adet (350 g) ekmek tüketildiği belirlenmiştir. Kişi başına geleneksel beyaz ekmek 2.3 adet $(575 \mathrm{~g})$, tam buğday ekmeği 1.3 adet $(325 \mathrm{~g})$ olarak tüketilmektedir. Tüketicilerin \%59.9'u aldıkları ekmeği aynı gün tüketmediklerini ve bu ekmeklerin \%10.1'ini hayvan beslemede kullanmak için bayat ekmek toplayan kişilere verildiklerini ifade etmişlerdir. Kalan ekmeklerin \%2.2'sinin ise çöpe atıldığı belirlenmiştir. Yapılan korelasyon analizi sonuçlarına göre; ekmek fiyatları satın alma gücü açısından farklı gelir düzeyindeki tüketicilere göre farklılık göstermektedir. Gelir düzeyi yüksek olan tüketiciler ekmek fiyatlarını düşük, geliri düşük olan tüketiciler ise ekmek fiyatlarını yüksek bulmuşlardır $(p<0.05)$. Gelir artışına bağlı olarak hane halkının aldığı toplam ekmek sayısı azalırken, gelir düzeyi düşük hanelerin satın aldığı toplam ekmek sayısının arttığı belirlenmiştir $(p<0.01)$.

Anahtar Kelimeler: Ekmek, tüketici, israf, Ankara

\section{Consumer Preferences in Bread in Ankara}

\section{Abstract}

This study was carried out to determine the factors affecting consumers' bread preferences in Ankara. The number of bread consumers to participate in the survey was determined by simple random sampling and surveys were conducted in 2015. As a result of the research, it was determined that 2.4 per day (600 g) per household and 1.4 per person $(350 \mathrm{~g}$ ) of bread were consumed in the province of Ankara. The traditional white bread is consumed as 2.3 pieces $(575 \mathrm{~g})$ and whole wheat bread as 1.3 pieces $(325 \mathrm{~g})$ per person. $59.9 \%$ of the consumers stated that they did not consume the bread they bought the same day and they were given to the people who collected stale bread to use $10.1 \%$ of these breads for animal feeding. It was determined that $2.2 \%$ of the remaining breads were garbage. According to the results of correlation analysis; Bread prices differ in terms of purchasing power from consumers with different income levels. Consumers with a high income level found bread prices low and consumers with low income found bread prices high $(p<0.05)$. It was determined that the total number of bread bought by the households with low income level increased while the number of total bread bought by the household decreased due to the income increase $(p<0.01)$.

Keywords: Bread, consumer, waste, Ankara

\section{Giriş}

B uğday, insan beslenmesinde önemli bir yere sahiptir. Tarımsal sanayiye hammadde sağlaması, ülke ekonomisine olan katkısı ve kırsal alanın başlıca gelir kaynağı olması açısından da Dünya'da ve Türkiye'de stratejik bir ürün konumundadır.
Buğday, buğday ürünleri ve ekmek hem geçmişte hem günümüzde Türk insanının en önemli besin kaynaklarındandır (Özberk ve ark. 2016). Ekmek ise en önemli buğday ürünü olması ve toplam gıda tüketimindeki payının yüksek olması nedeniyle, toplum 
beslenmesinde büyük önem arz etmektedir. Türkiye'de buğday yetiştirilen tüm alanlarda buğdayla bağlantılı en değerli ürün, ekmektir. Ekmek, Türk insanının gıda tüketiminde önemli bir yere sahiptir (Özberk ve ark. 2016).

Türk Gıda Kodeksi Ekmek ve Ekmek Çeşitleri Tebliğine göre ekmek; buğday ununa, su, tuz, maya (Saccharomyces cerevisiae) gerektiğinde şeker, enzimler, enzim kaynağı olarak malt unu, vital gluten ve izin verilen katkı maddeleri ilave edilip bu karışımın tekniğine uygun olarak yoğrulması, şekillendirilmesi, fermantasyona bırakılması ve pişirilmesi ile yapılan üründür. Ekmek çeşitleri ise ekmek tanımında geçen bileşenlere ilave olarak tahıl ürünlerini ve istenildiğinde çeşni maddelerini de içeren ve tekniğine uygun olarak üretilen ekmekleri ifade eder (Anonim 2012).

Fırıncılık ürünleri (ekmek, pasta ve kek) arasında en büyük paya sahip olan ekmek, Türkiye'de diyetin en önemli besin maddesidir. Türkiye'de günde 101 milyon, yılda 37 milyar adet ekmek üretilirken, günde 95 milyon, yılda ise 35 milyar adet ekmek tüketilmektedir. Günde 6 milyon adet, yılda ise 2.1 milyar adet ekmek israf edilmektedir, yani üretilen ekmeğin \%5.9'u israf edilmektedir (250 gr standart ekmek üzerinden hesaplanmıştır), (Anonim 2013). Ekonomik değer itibariyle bir kilo buğdayın, bir kilo ekmek olduğunu dikkate aldığında, 450500 bin ton buğday her yıl çöpe atılmaktadır.

Türkiye'de ekmek temel gıda maddesi olarak tüketilmektedir ve günlük kalori intiyacının \%44.0'ünü, protein ihtiyacının ise yaklaşık \%50.0'sini karşılamaktadır (Karaoğlu ve Kotancılar 2005). Ekmeğin beslenmede bu derece önemli olması; daha çok geleneksel beslenme alışkanlığından kaynaklanmaktadır. Bunun yanı sıra kolay ulaşılabilir ve düşük maliyetli olması, tok tutması, birçok yiyecekle birlikte tüketilebilmesi de diğer nedenlerdir (Elgün ve Ertugay 2002; Köten ve Ünsal 2006).

Türkiye, Dünyanın en fazla ekmek tüketen ülkelerinden birisidir. Literatürde dünya ve Türkiye'de ekmek ve tüketici ilişkisini araştıran çalışmalar mevcut olup (Armero and Collart 1998; Amid 2007; Anonymous 2012; Capone et al. 2016; Brancoli et al. 2017; Gül ve ark. 2003; Tanık 2006; Şahin ve Özer 2006; Açan 2007; Yılmaz ve Özkan 2007; Cop ve Doğan 2009; Bektaş ve Devran 2009; Aydın ve Yıldız 2011; Koç 2011; Demir ve Kartal 2012; Anonim 2013; Bal ve ark. 2013; Dölekoğlu ve ark. 2014; Ertürk ve ark. 2015) Ankara ilinde tüketicilerin ekmek tercihlerine ilişkin güncel çalışmalara rastlanılmamıştır. Bu çalışma ile tüketicilerin ekmek israfı ve değişen yasal mevzuata ilişkin farkındalıkları, ekmeği fazla tüketen bir toplum olarak, yıllardan beri ekmek alışkanlıklarındaki değişiklikler ve tüketimi yaygınlaşmaya başlayan kepekli, tam buğday ekmeği gibi çeşitli ürünlere olan talebin belirlenmesi amaçlanmıştır.

\section{Materyal ve Yöntem}

Çalışmanın materyalini, Ankara İlinde yaşayan tüketicilerle yüz yüze görüşmelerle doldurulan soru formlarından elde edilen veriler oluşturmuştur. Ankara ilinde Adrese Dayalı Nüfus Kayıt Sistemine (ADNKS) dahil olan toplam nüfus, popülasyonu oluşturmuştur. Araştırmanın planlandığı dönemde, Ankara İlinin toplam nüfusu 4.762.116'dır. Gerek araştırma alanının genişliği, gerekse zaman ve personel kısıtlarından dolayı; Ankara'da nüfusu 250.000'den fazla olan, sosyo-ekonomik göstergeler açısından da genel yapıyı gösterebilecek ve Ankara aktif nüfusunun yaklaşık \%85.0'ini temsil eden; Altındağ, Çankaya, Etimesgut, Mamak, Sincan ve Yenimahalle ilçeleri çalışma kapsamına alınmıştır. Seçilen 6 ilçenin aktif nüfusu (1464 yaş arası) 2.456.268'dir. Çalışmada popülasyonu temsil edecek örnek hacmi, basit tesadüfi örnekleme yöntemine göre, aşağıda belirtilen formül ile belirlenmiştir (Arıkan 1995).

$$
\begin{aligned}
& n=\frac{\text { Nxpxq }}{(N-1) \times D+p \times q} \\
& D=\left(\frac{E}{t}\right)^{2}
\end{aligned}
$$

\section{N : Popülasyon (2.456.268)}

$p$ : İncelenen olayın ana kitle içinde gerçekleşme olasılığı (Araştırma alanında, daha önce benzer bir çalışma yapılmadığı ve populasyonu temsil edecek maksimum örneğe ulaşmak için oran $\% 50$ alınmıştır.)

\section{$q$ : 1-p (0.50 alınmıştır.)}

$E$ : hata terimi $(0.05)$

t : güven aralığı \%95 (\%95 güven aralığının tablo değeri=1.96)

Yönteme göre örnek hacmi (n), 384 olarak hesaplanmıştır. Hesapla bulunan örnek hacmi, Ankara İlinde aktif nüfusu 250.000'den fazla olan 6 ilçenin aktif nüfusunun toplamdaki payları dikkate alınarak, ilçelere oransal dağıtıımıştır. 
Çizelge 1. Ankara ili tüketici örneklemi dağılımı

Table 1. Consumer sample distribution in Ankara province

\begin{tabular}{lccc}
\hline İlçeler & Toplam & $\%$ & $\mathrm{n}=384$ x ilçe ağırlığı \\
\hline Yenimahalle & 666.504 & 27 & 104 \\
Çankaya & 502.494 & 20 & 79 \\
Mamak & 396.823 & 16 & 62 \\
Sincan & 337.797 & 14 & 52 \\
Etimesgut & 305.334 & 12 & 48 \\
Altındağ & 251.316 & 10 & 39 \\
\hline Toplam & 2.456 .268 & 100 & 384 \\
\hline
\end{tabular}

\section{Bulgular ve Tartışma}

Tüketicilerinin Sosyoekonomik ve Demografik Yapısı

Araştırmanın gerçekleştirildiği Ankara ilinde anket yapılan tüketicilerin yaş ortalamaları 42 olup, en büyük 80 , en küçük 18 yaşındaki tüketicilerle görüşme gerçekleştirilmiştir. Tüketicilerin \%93.0'ü bayan olup, \%32.8'i lise mezunudur. Gelir durumu itibariyle ise tüketicilerin \%33.0'ünün aylık geliri 1001-2000 TL'dir. Tüketicilerin demografik özellikleri ile ilgili ayrıntııı çizelge aşağıdaki gibidir (Çizelge 2).

\section{Tüketicilerin Ekmek Tüketim Tercihleri}

Anket yapılan hanelerin \%68.3'ü gibi büyük bir oranında normal beyaz ekmek tüketilirken,
\%24.3 oranında hanede ise tam buğday ekmeği tüketilmektedir. Tam buğday ekmeği tüketim konusunda tüketicilerin eğilimlerinin arttığı belirlenmiştir. Yapılan diğer çalışmalarda da en fazla tüketilen ekmek çeşidinin geleneksel beyaz ekmek olduğu belirlenmiştir. Tokat ilinde \%70.6 (Gül ve ark. 2003), Tekirdağ'da \%78.0 (Tanık 2006), Van ilinde \%36.4 (Koç 2011), Konya ilinde \%75.0 (Demir ve Kartal 2012) oranında geleneksel beyaz ekmek tüketildiği tespit edilmiştir. Ekmek çeşitlerinin fazlalaşması ve tam buğday ekmek tüketimine yönelişe bağlı olarak Ankara ilinde geleneksel beyaz ekmek tüketiminin diğer illere göre daha az olduğu görülmüş, Doğu ve Güneydoğu Anadolu bölgesinde daha çok yöresel ekmeklerin tercih edilmesi geleneksel beyaz ekmeğe olan talebi azalttığı belirlenmiştir.

Çizelge 2. Tüketicilere ait bazı özellikler

Table 2. Some characteristics of the consumers

\begin{tabular}{llc}
\hline Özellik & Açıklama & Oran (\%) \\
\hline Cinsiyet & Kadın & 93.0 \\
& Erkek & 7.0 \\
\hline \multirow{4}{*}{ Eğitim durumu } & Okuryazar değil & 1.8 \\
& Okuryazar & 1.0 \\
& İlköğretim & 27.9 \\
& Lise & 32.8 \\
& Yüksekokul & 4.4 \\
& Üniversite & 28.9 \\
& Lisansüstü & 3.1 \\
\hline Hane halkı büyüklüğüü & $1-3$ kişi & 49.2 \\
& $4-6$ kişi & 48.2 \\
& $7-9$ kişi & 2.6 \\
\hline & $\leq 500$ TL/ay & 2.3 \\
& $501-1000$ TL/ay & 10.4 \\
& $1001-2000$ TL/ay & 33.3 \\
Gelir & $2001-3000$ TL/ay & 24.0 \\
& $3001-4000$ TL/ay & 17.7 \\
& $4001-5000$ TL/ay & 6.8 \\
& $5001+$ TL/ay & 5.5 \\
\hline
\end{tabular}


Ankara ilinde hane başına ortalama ekmek tüketimi 2.4 adet/gün $(600 \mathrm{~g})$ olarak bulunmuştur. Ekmek çeşitlerine göre tüketim incelendiğinde; normal beyaz ekmeğin hane başına tüketimi ortalama 2.3 adet/gün $(575 \mathrm{~g})$, tam buğday ekmeğinin 1.3 adet/gün, çavdarlı ekmeğin 0.9 adet/gün, kepekli ekmeğin 1.1 adet /gün olarak belirlenmiştir. Kişi başına ekmek tüketimi ise ortalama 1.4 adet/gün (350 g) olarak hesaplanmıştır. Yapılan korelasyon analizlerinde, geliri yüksek olan hane halkının aldığı toplam ekmek sayısı azalırken, geliri düşük olan hane halkının aldığı toplam ekmek sayısının arttığı belirlenmişsir $(p<0.01)$. Ekmek tüketim miktarı ile ilgili daha önce yapılan araştırmalarda kişi başı günlük ekmek tüketimi Ankara'da 327 g (Anonim 2013), Adana'da $233.5 \mathrm{~g}$ (Gül ve ark. 2003), Van'da 1.5 adet (Koç 2011) Tokat'ta 1.2 adet $(292 \mathrm{~g})$ (Bal ve ark.2013), Isparta'da 1.46 adet (Ertürk ve ark. 2015) olarak tespit edilmiştir. Bu sonuçlara göre Ankara ilinde kişi başına ekmek tüketiminin geçmiş yıllara göre arttığı ve diğer illerdeki tüketimlerden fazla olduğu belirlenmiştir.

Tüketicilerin \%40.1'i evlerine aldıkları ekmeğin tamamını aynı gün içinde tüketirken, \%59.9'unun aynı günde tüketemedikleri belirlenmiştir. Ekmeği aynı gün içinde tüketmeyenlerin, bayatlayan ekmekleri hangi şekilde değerlendirdikleri Çizelge $3^{\prime}$ te gösterilmektedir. Tüketicilerin \%87.7'sinin bayatlayan ekmekleri tekrar gıda olarak değerlendirdikleri (köfte yapımında, fırınlanarak çorbalara, yumurta ile kızartma), \%10.1'i kedi, köpek ve ineklerin beslenmesi amacıyla bayat ekmek toplayan kişilere ulaştırdıkları ve \%2.2'sinin ise bayat ekmekleri çöpe attığı gözlemlenmiş̧ir. Yapılan diğer araştırmalarda Cezayir, Mısır, Lübnan, Fas ve Tunus'ta eve alınan ekmek ürünlerinin \%20.0'sinin israf edildiği; özellikle Ramazan ayında ekmek israfının arttığı, İsveç'te süpermarket gıda atıklarının büyük bölümünün ekmek atıklarının oluşturduğu, Ingiltere'de bir yılda ekmeğin \%32'sinin israf edildiği, İran'da ise tüketilen 3 ekmekten birinin israf edildiği, Isparta ilinde günlük alınan ekmeklerin ortalama \%13.6'sının aynı gün içinde tüketilmediği, \%4.7'sinin bayatladığı ve \%1.2'sinin ise tüketilmediğinden dolayı küflendiği bildirilmiştir (Ertürk ve ark. 2015). Sivas ilinde ise tüketicilerin \%44.0'ünün ekmek israfı yaptığı ve israfın daha çok genç tüketiciler tarafından yapıldığı (Aydın ve Yıldız 2011), Adana ilinde satın alınan ekmeğin \%78.2'sinin bayatladığı, bayatlayan ekmeklerin ise \%80.4'ünün tekrar gıda olarak kullanıldığı, (Gül ve ark. 2003) Tekirdağ ilinde ise tüketicilerin \%64'ünün bayatlayan ekmekleri tekrar gıda olarak kullanırken \%16.0'sının hayvan beslenmesinde kullanıldığı, \%20.0'sinin ise çöpe atıldığını (Tanık 2006), Van ilinde tüketicilerin \%48.5'inin bayat ekmekleri tekrar gıda olarak değerlendirdikleri, \%40.5'inin hayvan beslenmesinde kullandıkları, \%5.7'sinin çöpe attıkları (Koç 2011), Isparta ilinde ise hanelerin \%54.4'ünün bayat ekmekleri hayvan beslenmesinde kullandıkları ve bu hanelerin \%84.9'u bayat ekmeklerin hayvanlara yedirimesinin israf olarak görmedikleri (Ertürk ve ark. 2015) belirlenmiştir. Türkiye genelinde (Adana, Ankara, Bursa, Erzurum, Gaziantep, İstanbul, İzmir, Kayseri, Malatya, Samsun, Tekirdağ ve Trabzon) yapılan araştırmada ise tüketicilerin gün içinde tüketemedikleri için bayatlayan ekmeklerin $\% 75.9$ 'u ile tatlı yaptıkları, \%52.7'sini intiyacı olanlara verdikleri, \%19.2'sini köfte harcı olarak kullandıkları, \%18.5'ini tost yaptıkları, $\% 17.7$ 'sini ısıtıp/kızartıp yeniden tükettikleri ve \%13.2'sini çorba/sulu yemekler ile birlikte farklı şekillerde değerlendirildiği tespit edilmiştir (Anonim 2013).

Tüketicilerin \%37.2'si, evlerine her gün

Çizelge 3. Tüketicilerin bayat ekmekleri değerlendirme şekilleri

Table 3. Evaluation of stale breads by consumers

\begin{tabular}{lc}
\hline Bayat Ekmeğin Değerlendirilme Şekli & Oran (\%) \\
\hline Tekrar gıda olarak değerlendiriliyor & 87.7 \\
Hayvan beslenmesinde kullanılıyor & 10.1 \\
Çöpe atılıyor & 2.2 \\
\hline Toplam & 100.0 \\
\hline
\end{tabular}

hanelerinde tüketecekleri miktardan daha fazla ekmek aldıklarını belirtmişlerdir. İhtiyaçtan daha fazla ekmek almanın nedenini; \%76.2'si evlerinde fazladan ekmek bulundurmayı istedikleri, \%14.0'ü misafir gelebilir düşüncesini taşıdıkları şeklinde ifade etmişlerdir. İtiyaçtan fazla ekmek almayı alışkanlık haline getiren tüketici oranı ise $\% 8.4$ 'tür.

Tüketicilerin \%62.0'si, son dönemlerde tükettiği ekmek çeşitlerinde bir değişiklik olduğunu bildirmiştir. Tüketim alışkanlıklarının değiştiğini belirtenlerin \%75.7'i tam buğday ekmeğine geçiş yaptığını, \%15.5’i kepekli ekmeğe yöneldiğini ifade etmiştir. 
Tüketicilerin \%37.8'inin hanelerinde günlük tükettikleri ekmek sayısında değişiklik olduğu dikkati çekmektedir. Tüketim değişimi olmayanların oranı ise \% 62.2'dir. Tükettikleri ekmek sayısında artış olanların oranının \%20.7, ekmek sayısını azaltanların oranının \%79.3 olduğu belirlenmiştir.

Hane nüfuslarının artmasına bağlı olarak ekmek tüketimi artan hanelerin oranı \%66.7'dir. Bununla birlikte tüketicilerin \%20.0'si beslenme alışkanlıklarındaki değişiklikler sebebiyle, \%13.3 'ü ise ekmek çeşitlerinin artmasına bağlı olarak, ekmeklerin daha lezzetli hale geldiğini düşünerek ekmek tüketimini artırdıklarını belirtmişlerdir. Tükettikleri ekmek sayılarında azalış olan hanelerin yaklaşık yarısı, sağlık nedenlerinden dolayı tüketimi azalttıklarını, $\% 20.0$ 'si hanelerindeki nüfus azalması, \%21.7'si beslenme alışkanlıklarındaki değişiklik ve \%5.2'si formda kalmak amaciyla ekmek sayısını azalttıklarını belirtmişlerdir.

Tüketicilerin $\% 38.5{ }^{\prime} \mathrm{i}$, son yıllarda tükettikleri ekmeklerin kalitesinde olumlu değişiklikler olduğunu düşünürken, $\% 61.5$ 'i herhangi bir olumlu değişiklik olmadığını aktarmışlardır (Çizelge 4 ve 5).

Çizelge 4.Tüketicilerin ekmek kalitesinde olumlu değişiklik olarak gördükleri özellikler

Table 4. Properties that consumers see as positive change in bread quality

\begin{tabular}{lc}
\hline $\begin{array}{l}\text { Ekmek Kalitesinde Görülen Olumlu } \\
\text { Değişiklikler }\end{array}$ & $\begin{array}{c}\text { Oran } \\
(\%)\end{array}$ \\
\hline Lezzeti artması & 60.1 \\
İçinin daha iyi pişmesi & 12.8 \\
Ambalaja girmesi & 8.8 \\
Çeşitlerin çoğalması & 6.1 \\
Tuzunun azalması & 5.4 \\
Renginin koyulaşması & 2.0 \\
Kokusunun iyileşmesi & 1.4 \\
Daha sağlıklı olması & 1.3 \\
İçeriğinin zenginleşmesi & 0.7 \\
Daha doyurucu olması & 0.7 \\
Katkı maddelerinin azalması & 0.7 \\
\hline Toplam & 100.0 \\
\hline
\end{tabular}

Tüketicilerin \%49.7'si son yıllarda tükettikleri ekmeklerin kalitesinde olumsuz değişiklikler olduğunu düşünürken, \%50.3'ü herhangi bir olumsuz değişiklik olmadığını düşünmektedir (Çizelge 5).
Çizelge 5. Tüketicilerin ekmek kalitesinde olumsuz değişiklik olarak gördükleri özellikler

Table 5. Properties that consumers see as a negative change in bread quality

\begin{tabular}{lc}
\hline Ekmek kalitesinde görülen olumsuz & $\begin{array}{c}\text { Oran } \\
\text { değişiklikler }\end{array}$ \\
\hline İçinin iyi pişmemesi & 28.8 \\
Lezzetinin eskisi gibi olmaması & 26.7 \\
Katkı maddelerinin artması & 11.5 \\
İçinin boşalması & 11.0 \\
Mayasının fazla olması & 4.2 \\
İçinden yabancı madde çıkması & 3.7 \\
Kokusunun değişmesi, kötüleşmesi & 2.6 \\
Dışının çabuk sertleşmesi & 2.1 \\
Gramajının azalması & 1.0 \\
Tuz oranının fazlalaşması & 1.0 \\
Tam buğday ekmeğinin doğal olmaması & 1.0 \\
Ambalajsız satılması & 1.0 \\
Çabuk bayatlaması & 1.0 \\
Çabuk küflenmesi & 1.0 \\
Hijyene dikkat edilmemesi & 1.0 \\
Hamurlaşma olması & 0.5 \\
Gramajının eksik çıkması & 0.5 \\
Şeklinin bozulması & 0.5 \\
Gramajının düşürülmesi & 0.5 \\
\hline Toplam & 100.0 \\
\hline
\end{tabular}

Türk Gıda Kodeksi Ekmek ve Ekmek Çeşitleri Tebliğinde (Tebliğ No: 2012/2) değişiklik yapılmış (Tebliğ No: 2013/10) tuz oranı en çok kuru maddede \%1.75'den \%1.5'e düşürülmüştür. Tüketicilerin $\% 5.4$ 'ü ekmekte tuzun azalmasını fark ederek, ekmek kalitesinde olumlu değişiklik olarak görmüşlerdir. \%1'i ise ekmekte tuz oranının azaldığını fark etmediklerini, tuz miktarının halen yüksek ve bunun ekmek kalitesinde olumsuz bir değişiklik olduğunu belirtmişlerdir. Diğer bütün olumsuz değişiklikler, ekmek üretiminin optimum ve hijyen koşullarda gerçekleştirilmemesinin bir sonucu olarak değerlendirilebilir. Fermantasyon süreleri, kullanılan maya ve diğer enzim katkı miktarları ve en önemlisi un kalitesi olumsuz değişiklik olarak ifade edilen sonuçların sebebidir (Çizelge 5).

Tüketicilerin \%83.3'ü, ekmek yapımında kullanılan un kalitesinin, ekmek kalitesine etki eden en önemli kriter olduğunu ifade etmiştir. Ekmeğin kalitesine etki eden diğer önemli faktörler; katkı, maya, ustalık ve pişirilme tekniği olarak sıralanabilir.

Tüketicilerin \%4.7'si diyet amaçlı ekmek tüketmektedir. Diyet amaçlı ekmek tüketenlerin 
\%77.8'i tuzsuz ekmek, \%11.1'i tam buğday ekmeği, \%5.6'sı glutensiz ekmek ve \%5.5'i denge ekmeği tükettiklerini belirtmişlerdir.

Tüketicilerin \%31.8'inin ekmeklerini kendi evlerinde yapmayı tercih etmektedir. Evinde ekmek yapan tüketicilerin, ekmek yapma sıklıkları; \%68'inin ara sıra, \%9'unun her hafta, \%1.6'sının her gündür. Yapılan korelasyon analizlerinde; hane geliri yüksek olan tüketicilerin evde ekmek yapma alışkanlıkları, hane geliri düşük olan tüketicilere göre daha fazla bulunmuştur $(p<0.01)$. Tüketicilerin $\% 22.4$ 'ü, satın aldıkları ekmeklerin üretildiği ortam hakkında bilgileri olduğunu, \%77.6'sı ekmeğin nerede ve hangi fiziki ortamda üretildiği konusunda bilgi sahibi olmadıklarını belirtmişlerdir. Aynı zamanda; \%80.5'i ekmeğin üretildiği ortam ve koşullarını merak ettiklerini aktarmışlardır. Tüketicilerin tamamına yakını (\%97.7) hijyen ve temizlik kurallarına uygun olarak ekmek üretilip üretilmediğini merak ekmektedirler. Ekmek yapımında katkı maddesi kullanılıp kullanılmadığı ve kullanılan unun kalitesi, fırınlar hakkında merak edilen ikinci önemli konudur. Bu sonuçlar; üretilen ekmeğin fiziki şartlarının ve ekmeğin yapısını oluşturan temel kriterlerin uygunluğunun tüketiciler tarafından merak edildiğini ve yerinde görmek istediğini ortaya koymaktadır.

Tüketicilerin ekmeği satın aldıkları yerlerin $\% 50.0$ 'sinde ekmek için ayrı bir satış dolabı olduğu, \%23.2'sinde kasalar içinde, \%25.0'inde tezgah üzerinde açıkta satılığı, tüketiciler tarafından aktarılmıştır.

Tüketicilerin $\% 52.5$ 'i tarafından ekmeği satın aldıkları yerlerde ekmeğin satış şeklinden rahatsız olduklarını ifade etmiştir. Ekmeğin sunumu ile ilgili olarak tüketicilerin rahatsız olduğu sorun alanları Çizelge 6'da gösterilmektedir. Çizelge incelendiğinde; tüketicilerin \%57.4'ünün ekmeklerin açıkta satışa sunulduğu ve satın alırken ekmeğe çoğu müşterinin elinin temas ettiği şeklinde rahatsızlıklarını ifade ettikleri görülmektedir. Ayrıca üstü açık olarak satışa sunulan ekmeklerin tozla temasından rahatsız olan tüketicilerin oranı ise \%34.0'dür. Diğer bir rahatsızlık ise, ekmeklerin fıınlardan satış noktalarına nakliyesinde kullanılan kasaların açık şekilde bulunmasıdır. Ancak Ekmek ve Ekmek Çeşitleri Tebliği kapsamında bu husus açıkça ifade edilmektedir; "ambalajsız olarak piyasaya arz edilen ürünler; satış yerlerinde alıcının el temasını engelleyecek şekilde ekmek dolabında veya tezgâhında muhafaza edilerek gıda işletmecisinin kontrolünde satılır veya gıda işletmecisi, tüketicinin bu ürünleri eldiven ile almasını sağlar". Tüketiciler bu konuda yeterli denetim ve yaptırımların uygulanması hususundaki beklentilerini de dile getirmişlerdir

Çizelge 6. Ekmek satın alınan yerlerde ekmeğin satışında / sunumunda tüketicileri rahatsız eden konular

Table 6. Issues that annoy consumers in the sale / presentation of bread in places where bread is bought

\begin{tabular}{lc}
\hline $\begin{array}{l}\text { Ekmek Satışında Tüketicileri Rahatsız } \\
\text { Eden Konular }\end{array}$ & $\begin{array}{c}\text { Oran } \\
(\%)\end{array}$ \\
\hline $\begin{array}{l}\text { Ekmeklerin açıkta satılması, herkesin } \\
\text { dokunması }\end{array}$ & 57.4 \\
Üstü açık olduğu için tozla temas etmesi & 33.7 \\
$\begin{array}{l}\text { Ekmeklerin kasaların üzeri açık şekilde } \\
\text { nakliye edilmesi }\end{array}$ & 6.9 \\
Fırıncıların hijyene dikkat etmemesi & 2.0 \\
\hline Toplam & 100.0 \\
\hline
\end{tabular}

Tüketicilerin ekmek satın alırken dikkat ettikleri en önemli kriterler Çizelge 7'de tercih sırasına göre verilmiştir. Tüketicilerin $\% 80$ 'i ekmekte en önemli kriterin hijyen olduğunu belirtirken, ekmeğin görünüşü ve kabarık olmasını da ikinci kriter olarak belirtmişlerdir. Diğer önemli kriter ise ekmeğin sıcak olmasıdır. Daha önce yapılmış olan çalışmalarda da benzer sonuçlar elde edilmiştir; Isparta ilinde tüketicilerin ekmek satın alma kriterlerinde \%83.3 oranında hijyenin ilk sırada (Ertürk ve ark. 2015), Türkiye genelinde yapılan bir araştırmada ise tüketicilerin ekmek satın alma kriterlerinde \%54.6 oranında ekmeğin sıcak

Çizelge 7. Tüketicilerin ekmek satın alırken karar vermelerini etkileyen en önemli kriterler

Table 7. The most important criteria affecting consumers' decision to buy bread

\begin{tabular}{lcc}
\hline Kriterler & 1. Tercih & 2. Tercih \\
\hline Hijyenik olması & 79.2 & 10.4 \\
Sıcak olması & 4.2 & 27.6 \\
Görünüşü, kabarık olması & 5.5 & 17.9 \\
Katkı ve içeriği & 2.6 & 12.3 \\
Fiyatı & 3.1 & 6.3 \\
Pişirilen fırın tipi & 1.6 & 8.2 \\
Ekmeğin kızarması & 2.1 & 9.7 \\
Ambalajlı satışın olması & 1.3 & 6.3 \\
Kokusu & 0.3 & - \\
Markası & 0.3 & 0.7 \\
Lezzeti & - & 0.4 \\
\hline Toplam & 100.0 & 100.0 \\
\hline
\end{tabular}


ve taze olmasının ilk sırada, \%47.9 oranında ekmeğin iyi pişmiş olmasının ikinci sırada (Anonim 2013) yer aldığı tespit edilmiştir.

Tüketicilerin \%49.0'u ekmek fiyatlarını pahalı bulurken, \%49.2'si normal, \%1.3'ü ucuz ve $\% 0.5$ 'i çok pahalı bulmaktadır. Ekmek fiyatlarını pahalı bulan tüketiciler, tam buğday ekmeği, kepek ekmeği gibi ekmek çeşitlerini normal ekmeğe göre daha pahalı olması nedeniyle tüketemediklerini ifade etmişlerdir. Ekmek fiyatlarını ucuz bulan tüketiciler, ekmek israfı çok fazla olduğundan, ucuz bulduklarını ifade etmişlerdir. Ekmek fiyatları ile ekmek satın alma gücü arasında korelasyon olup olmadığını belirlemek amacıyla yapılan korelasyon analizi sonucuna göre; ekmek fiyatlarının satın alma gücü açısından farklı gelir düzeyindeki tüketicilere göre değişiklik gösterdiği belirlenmiştir. Gelir düzeyi yüksek olan tüketiciler ekmek fiyatlarını düşük bulurken, gelir düzeyi düşük olan tüketiciler ekmek fiyatlarını yüksek bulmuşlardır $(p<0.05)$. Aynı zamanda ekmek fiyatları satın alma gücü açısından farklı ilçelerdeki tüketicilere göre de farklılık göstermiştir $(p<0.05)$.

Tüketicilerin \%31.8'inin en az bir tane ekmek markası bilmelerine rağmen, \%68.2'si hiçbir ekmek markasını bilmemektedir. \%82.8 oranında en fazla tanınan ekmek markası Uno olarak belirlenmiştir. Daha sonra sırasıyla Halk Ekmek, Yepaş, Ekmecik ve Untad gelmektedir. Yapılan korelasyon analizinde eğitimi yüksek olan tüketicilerin en az bir ekmek markası bilme durumlarının, eğitimi düşük olan tüketicilere göre daha fazla olduğu belirlenmiştir $(p<0.01)$.

Tüketicilerin buğday çeşitleri hakkında bilgilerini ve farkındalıklarını belirlemek amacıyla buğday çeşitlerini bilip bilmedikleri sorusu yöneltilmiştir. Tüketicilerin \%23.2'si en az bir buğday çeşidinin ismini aktarabilmişlerdir. Tüketicilerin ifade ettikleri buğday çeşitlerinin bazıları yerel çeşitler, bazıları tescilli buğday çeşitleri olup, bazıları da yöresel isim veya kendilerinin adlandırdıkları isimlerdir (Çizelge 8).

Tüketicilerin ifade ettikleri buğday isimleri içinde ön plana çıkan \%21.3 oranı ile esmer buğday diye nitelendirdikleri isim olmuştur (Çizelge 9). Esmer buğday tescilli bir çeşit adı olmayıp, genel anlamda kırmızı taneli ekmeklik buğday şeklinde anlatılmak istendiği düşünülmektedir. Tüketicilerin $\% 50.0$ 'den fazlası tescilli çeşit isimlerini bilmemektedir. Hatta ekmeklik buğday ve makarnalık buğday tür isimlerini çeşit ismi olarak algılamaktadır. \%28.0'i ise tescilli bir çeşit ismini bilmektedir, ancak ekmeklik ve makarnalık buğday çeşit isimleri karışık olarak söylenmektedir. Un sanayinin en çok tercih ettiği çeşitlerden biri olan Tosunbey çeşidinin ismini bilen tüketicilerin oranı \%2.2'dir.

Çizelge 9. Tüketiciler tarafından bilinen buğday çeşitlerinin oranı

Table 9. Percentage of wheat varieties known by consumers

\begin{tabular}{lcc}
\hline Buğday Çeşitleri & Frekans & Oran (\%) \\
\hline Esmer buğday & 19 & 21.3 \\
Kunduru & 12 & 13.5 \\
Kara buğday & 8 & 9.0 \\
Bezostaja 1 & 6 & 6.7 \\
Sert buğday & 6 & 6.7 \\
Kırmızı buğday & 5 & 5.6 \\
Sarı buğday & 4 & 4.5 \\
Beyaz buğday & 3 & 3.4 \\
Durum buğdayı & 3 & 3.4 \\
Gün 91 & 3 & 3.4 \\
Tosunbey & 2 & 2.2 \\
Cumhuriyet & 2 & 2.2 \\
Siyah buğday & 2 & 2.2 \\
Ekmeklik buğday & 2 & 2.2 \\
Diğer & 12 & 13.7 \\
\hline Toplam & 89 & 100.0 \\
\hline
\end{tabular}

Çizelge 8. Tüketiciler tarafından bilinen buğday çeşitleri Table 8. Wheat varieties known by consumers

\begin{tabular}{ll}
\hline Tescilli Olmayan Buğday İsimleri & Tescilli Çeşitler \\
\hline Beyaz buğday, Rus buğdayı, Sivas buğdayı, Çorum buğdayı, Sert & Tosunbey, Kate A 1, \\
buğday, Sarı Bursa, Sarı buğday, Hatay buğdayı, Kılçıksı, Üveyik, & Pehlivan, Flamura-85, \\
Çalıbasan, Ağ buğday, Meksika buğdayı, Kaplıca, Esmer buğday, & Gün 91, Gerek 79, \\
Kara buğday, Kırmızı buğday, Kızıl buğday, Kılçıklı, Siyah buğday, & Bezostaja 1, Ceyhan 99, \\
Kısabacak, Zerun, Kaplıca, Şahman, Makarnalık buğday, Durum & Cumuriyet 75 Kızıltan \\
buğdayı, Ekmeklik buğday, & Kunduru 1149 \\
& \\
\hline
\end{tabular}




\section{Mevzuata Uyum}

Araştırmada, 04.01.2012 tarihli ve 28163 sayılı Resmi Gazete'de yayımlanan "Türk Gıda Kodeksi Ekmek ve Ekmek Çeşitleri Tebliği'”nde (Tebliğ No: 2012/2) yapılan değişiklikler hakkında tüketicilerin, ekmek fırını sahiplerinin ve un sanayicilerinin görüşleri ve uygulamalar hakkındaki düşünceleri belirlenmiştir.

Tebliğin Ek-2 bölümünde belirlenen "Ambalajsız Olarak Piyasaya Arz Edilen Ürünlerin Üretim, Depolama, Dağıtım ve Satış Aşamalarının Taşıması Gereken Kurallar" bölümünde yer alan hükümlerden "Bu Tebliğ kapsamında yer alan ürünleri tüketiciye arz eden yerler; tam buğday ekmeği ve/veya tam buğday unlu ekmek ve/veya kepekli ekmek de bulundurmak zorundadır." ibaresinin uygulanış biçimi hakkında tüketicilerin düşünceleri Çizelge 10'daki gibidir.

Katkı maddeleri ile ilgili olarak Ekmek Tebliği'nde yer alan tanımlamalar şu şekildedir:

- Türk Gıda Kodeksi Gıda Katkı Maddeleri Yönetmeliği'nde izin verilen katkılardan hiç biri katılmaz ise ürün adı ile birlikte "katkısız" ifadesi kullanılabilir.

- Ayrıca Tebliğ kapsamında yer alan ürünlerde kullanılan katkı maddeleri, 29.12.2011 tarihli ve 28157 No'lu Resmi Gazete'nin 3. mükerrer sayısında yayımlanan Türk Gıda

Çizelge 10. Tüketicilerin ekmek satış noktalarında 'tam buğday ekmeği, tam buğday unlu ekmek ve/ veya kepekli ekmek' bulundurulma zorunluluğu konusunda düşünceleri

Table 10. Consumers' thoughts on the necessity of having 'full wheat bread, whole wheat flour and / or whole wheat bread' on bread sales points

\begin{tabular}{lc}
\hline Tüketicilerin Düşünceleri & $\begin{array}{c}\text { Oran } \\
(\%)\end{array}$ \\
\hline $\begin{array}{l}\text { Biliniyor, iyi bir uygulama ve alternatif için } \\
\text { iyi olduğu, istenilen yerde bulunduğunun } \\
\text { düşünülmesi }\end{array}$ & 54.4 \\
$\begin{array}{l}\text { Uygulamadan haberleri var, ama her } \\
\text { yerde bulunmadığının düşünülmesi }\end{array}$ & 18.5 \\
$\begin{array}{l}\text { Uygulamadan haberleri yok, ama iyi bir } \\
\text { uygulama olduğunun düşünülmesi }\end{array}$ & 19.0 \\
$\begin{array}{l}\text { Fikri yok } \\
\text { Her yerde bulundurulduğunu bilmelerine } \\
\text { rağmen kendilerinin evde yapmaları }\end{array}$ & 3.1 \\
$\begin{array}{l}\text { Tam buğday ve kepekli ekmeğin gerçek } \\
\text { olmadığının düşünülmesi }\end{array}$ & 1.3 \\
$\begin{array}{l}\text { Zorunlu olmasının iyi bir uygulama } \\
\text { olmadığının düşünülmesi }\end{array}$ & 0.3 \\
\hline Toplam & 100.0 \\
\hline
\end{tabular}

Kodeksi Gıda Katkı Maddeleri Yönetmeliğinde yer alan hükümlere uygun olur.

Tüketicilere, Ekmek ve Ekmek Çeşitleri Tebliğinde belirtilen katkı maddelerinden bazılarının kullanımının yasaklanması ile ilgili görüşleri sorulduğunda; \%26.1'i uygulamayı duyduklarını, ancak katkı maddesi kullanımının uygulamada halen devam ettiğini düşündüklerini belirtmişlerdir. Tüketicilerin \% 24.8'inin ise Tebliğ hakkında bilgi sahibi oldukları, iyi bir uygulama ve olumlu bir gelişme olarak gördükleri belirlenmiştir. Tüketiciler tarafından, Tebliğde ekmek üretiminde kullanımına izin verilen enzimlerin, katkı maddesi olarak algılandığı düşünülmektedir (Çizelge 11).

Çizelge 11. Tüketicilerin ekmek üretiminde katkı maddelerinin kaldırılması hakkındaki düşünceleri

Table 11. Consumers' thoughts on the removal of additives in bread production

\begin{tabular}{|c|c|c|}
\hline Tüketicilerin Düşünceleri & Frekans & $\begin{array}{c}\text { Oran } \\
(\%)\end{array}$ \\
\hline $\begin{array}{lr}\text { Uygulamadan } & \text { haberleri } \\
\text { var, ama } & \text { kaldırıldığına } \\
\text { inanmamaları } & \end{array}$ & 100 & 26.1 \\
\hline $\begin{array}{l}\text { Uygulamadan haberleri var } \\
\text { ve iyi bir uygulama olduğunun } \\
\text { düşünülmesi }\end{array}$ & 95 & 24.8 \\
\hline Anlaşılmadığının düşünülmesi & 58 & 15.1 \\
\hline $\begin{array}{l}\text { Uygulamadan haberlerinin } \\
\text { olmaması, ama iyi bir } \\
\text { uygulama } \\
\text { düşünülmesi }\end{array}$ & 50 & 13.0 \\
\hline Fikri yok & 46 & 12.1 \\
\hline $\begin{array}{lr}\text { Tüm katkı } & \text { maddelerinin } \\
\text { kaldırılması } & \text { gerektiğinin } \\
\text { düşünülmesi } & \end{array}$ & 34 & 8.9 \\
\hline Toplam & 384 & 100.0 \\
\hline
\end{tabular}

Aynı Tebliğde yapılan değişiklikle ekmek ve ekmek çeşitlerindeki tuz miktarının \%1.75'ten \%1.5'e azaltılması uygulamasının, tüketicilerin \%46.6'sı tarafından hissedildiği ve olumlu görüldüğü belirlenmiştir. Diğer yandan, tüketicilerin \%30.5'i ise ekmekteki tuz miktarının azalmasını hissetmediklerini belirtmiştir (Çizelge 12).

Ekmek ve Ekmek Çeşitleri Tebliği yürürlüğe girmeden önce ekmeklik buğday unundaki kül miktarı 0.55 , düzenlemeden sonra 0.65 iken, son değişiklikle en az 0.70 en çok 0.80 olmuştur. Tam buğday unundaki kül miktarı ise 1.20 olarak belirlenmiştir. Buğdaydan üretilen unun randımanında ise önceki düzenlemeyle 
Çizelge 12.Tüketicilerin ekmekte tuz miktarının azaltılması konusunda düşünceleri

Table 12. Consumers' thoughts on reducing the amount of salt in bread

\begin{tabular}{lcc}
\hline Tüketicilerin Düşünceleri & Frekans & $\begin{array}{c}\text { Oran } \\
(\%)\end{array}$ \\
\hline $\begin{array}{l}\text { Azaldığının hissedilmesi, } \\
\text { olumlu bir karar olduğunun } \\
\text { düşünülmesi }\end{array}$ & 179 & 46.6 \\
$\begin{array}{l}\text { Hissedilmediğinin düşünülmesi } \\
\text { Doğru bir karar olduğunun } \\
\text { düşünülmesi }\end{array}$ & 117 & 30.5 \\
$\begin{array}{l}\text { Uygulamadan haberlerinin } \\
\text { olmaması ama iyi bir uygulama } \\
\text { olduğunun düşünülmesi }\end{array}$ & 23 & 9.9 \\
$\begin{array}{l}\text { Fark edilmediğinin düşünülmesi } \\
\text { Fikri yok }\end{array}$ & 16 & 4.2 \\
$\begin{array}{l}\text { Tuzlu ve tuzsuz olmalı. } \\
\text { isteyenin istediğini almasının } \\
\text { düşünülmesi }\end{array}$ & 2 & 0.5 \\
\hline \begin{tabular}{l} 
Toplam \\
\hline
\end{tabular} & 384 & 100.0 \\
\hline
\end{tabular}

Çizelge 13. Tüketicilerin unda; kül, lif ve vitamin miktarlarının arttırııması konusundaki düşünceleri Table 13. Consumers' thoughts on increasing amounts of ash, fiber and vitamins in flour

\begin{tabular}{lcc}
\hline Tüketicilerin düşünceleri & Frekans & Oran (\%) \\
\hline $\begin{array}{l}\text { Hissedilmediğinin,anlaşı- } \\
\text { madığının düşünülmesi }\end{array}$ & 161 & 41.9 \\
$\begin{array}{l}\text { Uygulamadan haberleri var, } \\
\text { olumlu bir karar olduğunun } \\
\text { düşünülmesi }\end{array}$ & 101 & 26.3 \\
$\begin{array}{l}\text { Fikri yok, bilgisi yok } \\
\text { Hissedildiği, renginin } \\
\text { koyulaştığı, lezzetinin } \\
\text { arttığının düşünülmesi }\end{array}$ & 42 & 10.9 \\
$\begin{array}{l}\text { Uygulamadan haberlerinin } \\
\text { olmaması ama iyi bir karar } \\
\text { olduğunun düşünülmesi }\end{array}$ & 16 & 10.4 \\
$\begin{array}{l}\text { Doğal buğday ve un olması } \\
\text { gerektiğinin düşünülmesi }\end{array}$ & 12 & 3.2 \\
$\begin{array}{l}\text { Anlaşılamayacağının } \\
\text { düşünülmesi }\end{array}$ & 9 & 2.3 \\
$\begin{array}{l}\text { Uygulamanın hayata } \\
\text { geçirildiğine inanmamaları }\end{array}$ & 3 & 0.8 \\
\hline Toplam & 384 & 100.0 \\
\hline
\end{tabular}

100 kilogram buğdaydan 65 kilogram ekmeklik un elde edilirken, yeni düzenleme ile daha fazla $(70-80 \mathrm{~kg})$ un elde edilmektedir. Böylelikle ekmeklik buğday ununun kül miktarına bağlı olarak un üretiminde kullanılan buğdayda önemli oranda tasarruf sağlanmış olacaktır.
İnsan beslenmesinde çok olumlu etkileri olacak bir uygulama olup, kül miktarı yüksek olan buğday unlarının lif ve vitamin miktarları da yüksek olmaktadır. Bu uygulamanın tüketicilerin \%41.9'u tarafından ekmekte hissedilmeği belirlenmiştir. Tüketicilerin \%26.3'ü ise uygulamadan haberdar olduğunu ve olumlu bir gelişme olarak gördüğünü belirtirken, \%10.9'u uygulamayı hiç duymadığını, bilgisinin olmadığını ve \%10.4'ü ise ekmeğin lezzetinden ve renginin koyulaşmasından bu değişikliği fark ettiklerini ifade etmişlerdir (Çizelge 13).

Tüketicilerin çoğu, ekmekle ilgili gelişmeleri basılı ve görsel yayından takip ettiklerini, özellikle esmer ekmek ile ilgili tüketim kararını vermede, televizyondaki sağlık programlarından etkilendiklerini belirtmişlerdir.

\section{Sonuç}

Araştırma sonucunda; Ankara ilinde kişi başına ekmek tüketiminin 1.4 adet/gün (350 g) olduğu belirlenmiştir. Tüketicilerin büyük bir bölümü aldıkları ekmeği aynı gün içinde tüketmemektedirler. Bu durum, tüketicilerin evlerine günlük intiyaçlarından daha fazla ekmek aldıklarını ve israfa neden olduğunu göstermektedir. İhtiyaç duyulan miktarda ekmek satın alınması ve satın alınan bu ekmeklerin doğru bir şekilde muhafaza edilmesi konularında tüketiciler için farkındalık çalışmalarının arttırılarak devam ettirilmesi gerekmektedir.

Gıda israfı, giderek artan doğal kaynakların sürdürülebilirliği riskini de etkilemektedir. Gıda israfı sadece tüketicinin cebindeki kayıp değil, aynı zamanda bu gıdaların sofraya gelinceye kadar olan tüm katma değer süreçlerindeki ekonomik ve çevresel kayıplardır (Dölekoğlu 2014). Ankara'da oluşan ekmek israflarının ve israf kaynaklı ekonomik kayıpların önüne geçebilmek için, kamu kurum ve kuruluşları, belediyeler, üniversiteler, sivil toplum kuruluşları, özel sektör, meslek örgütleri ve medya kuruluşları ile işbirliği yapılarak toplumun her kesimine ulaşan, farklı ölçeklerde bilgilendirme ve bilinçlendirme projeleri ve çalışmalarına ağırlık verilmelidir. Ayrıca tüketicilerin, fırınların, belediyelerin, sivil toplum kuruluşların, üniversitelerin ve kamu kuruluşlarının birlikte hareket edeceği üretim ve tüketim planlamasının uygulanması gerekmektedir. Farkındalık ve eğitim çalışmalarının etkisini arttırabilmek amacıyla; yaş grupları ve mesleki alanlar için farklı çalışmaların yürütülmesinin ve küçük 
yaş gruplarından başlamanın etkili olacağı düşünülmektedir. Bu nedenle, okullarda israf konusuna dikkat çekilmeli ve ev hanımlarına yönelik çalışmalara ağırlık verilmelidir.

\section{Teşekkür}

Bu çalışmada, Gıda Tarım ve Hayvancılık Bakanlığı, Tarımsal Araştırmalar ve Politikalar Genel Müdürlüğü tarafından desteklenen TAGEM / TEAD /14/ A15/ P02/ 001 numaralı "Ankara İlinde Buğday Çeşitlerinin Un Sanayisinde Kullanım Durumu, Ekmek Fırınlarının Un Tercihi Ve Ekmekte Tüketici İstekleri" isimli projeden elde edilen verilerden yararlanılmıştır.

\section{Kaynaklar}

Açan B., 2007. Kolayda mallarda müşteri profili ve tüketim tercihleri: İstanbul Halk Ekmek müşterilerine yönelik bir araştırma. Atatürk Üniversitesi İktisadi ve İdari Bilimler Dergisi 21, no. 2 (2007): 261-280

Amid J., 2007. The dilemma of cheap food and selfsufficiency: The case of wheat in Iran. Food Policy, 32: 537-552

Anonim, 2001. Hayvancılık Özel İhtisas Komisyon Raporu. DPT, Ankara

Anonim, 2012. http://mevzuat.basbakanlik. gov.tr/Metin.Aspx? MevzuatKod= 9.5.15746\&Mevzuatlliski=0\&source XmlSearch=ekmek (Erişim Tarihi: 15.03.2017)

Anonim, 2013.Toprak Mahsulleri Ofisi. Türkiye'de ekmek israfı araştırması (Ekmek tüketimiyle ilgili tutum ve davranışlar ile ekmek israfı ve israf üzerinde etkili olan faktörler araştırması). TMO, 2. Baskı, Şubat, Ankara

Anonymous, 2012. DEFRA (Department for Environment, Food and Rural Affairs). Food Statistics Pocketbook, UK

Arikan R., 1995. Araştırma Teknikleri ve Rapor Yazma. Ankara: Tutibay yayınları

Armero E. and Collart C., 1998. Crumb firming kinetics of wheat breads with anti-staling additives. Journal of Cereal Science, 28: 165-174

Aydın F. ve Yıldız Ş., 2011. Sivas ilinde ekmek tüketim alışkanlıkları ve tüketici dinamiklerinin belirlenmesi. Atatürk Üniv. Ziraat Fak. Derg. 42(2): $165-180$

Bal Z. E., Sayılı M. ve Gözener M., 2013. Tokat ili merkez ilçede ailelerin ekmek tüketimleri üzerine bir araştırma. JAFAG 30(1): 61-69

Bektaş F., Davran M.K., 2009. Gıda tüketim davranışlarında değişme ve kırsal kesim. VI. Ulusal Sosyoloji Kongresi, 1-3 Ekim 2009 Aydın, s.764-786
Brancoli P., Rousta K. and Bolton K., 2017. Life cycle assessment of supermarket food waste. resources, conservation and recycling, 118:39-46

Cop R. ve Doğan H., 2009. Ekmek üretiminde yeni ürün geliştirme ve tüketici tutumlarıyla ilgili bir uygulama. Abant İzzet Baysal Üniversitesi Sosyal Bilimler Enstitüsü Dergisi, 1(18): 12-26

Capone R., Bilali H.E., Debs P., Bottalico F., Cardone G., Berjan S., Elmenofi G.A.G., Abouabdillah A., Charbel L., Arous S.A., Sassi K., 2016. Bread waste in Mediterranean Arab countries. $5^{\text {th }}$ International Symposium On Agricultural Sciences, February 29 - March 3, Banja Luka, Bosnia and Herzegovina Abstract Book s.220

Demir M. K. ve Kartal H., 2012. Konya ilinde farklı ekmek çeşitlerini tüketen bireyler üzerinde yapılan bir anket çalışması. Gıda Teknolojileri Elektronik Dergisi, 7(3): 59-64

Dölekoğlu C Ö., Giray H F. ve Şahin A., 2014. Mutfaktan Çöpe Ekmek: Tüketim ve Değerlendirme, Akademik Bakış Dergisi, İktisat ve Girişimcilik Üniversitesi, Türk Dünyası Kırgız-Türk Sosyal Bilimler Enstitüsü,, ISSN:1694-528X CelalabatKırgızistan Sayı:44

Elgün A. ve Ertugay Z., 2002. Tahıl İşleme Teknolojisi. Atatürk Üniversitesi Ziraat Fakültesi Yayınları No: 297, Ders Kitapları Serisi No: 52, Erzurum, 481s.

Ertürk A., Arslantaş N., Sarıca D., Demircan V., 2015, Isparta İli kentsel alanda ailelerin ekmek tüketimi ve israfı, Akademik Gıda 13(4): 291-298

Gül A., Işık H., Bal T. ve Özer S., 2003. Bread consumption and waste of households in urban area of Adana province. EJPAU 6(2): 10-16

Karaoğlu M. ve Kotancılar G., 2005. Ekmek içi yumuşaklık üzerine kısmi pişirme yöntemi ve depolama şartlarının etkisi. Atatürk Üniversitesi Ziraat Fakültesi Dergisi 30(2): 117-122

Koç B., 2011. Ekmek tüketiminde tüketici tercihleri: Van ili örneği. Tarımsal Ekonomi ve Politika Geliştirme Enstitüsü Yayını, TEPGE Yayın No: 196, Ankara.

Köten M. ve Ünsal S., 2006. Şanlıurfa yöresine özgü tırnaklı ve açık ekmeklerin bazı kimyasal bileşimlerinin belirlenmesi üzerine bir araştırma. Harran Üniversitesi Ziraat Fakültesi Dergisi, 10(3/4): 57-62 
Taşcı et al. "Consumer Preferences in Bread in Ankara"

Mena C., Diaz B.A., Yurt Ö., 2011. The causes of food waste in the supplier-retailer interface: Evidences from the UK and Spain. Resources, Conservation and Recycling, 55(6):648-658

Şahin A. ve Özer B.Ş., 2006. Beslenme kültüründeki farklılıkların bayan tüketicilerin gıda satın alma davranışları üzerindeki etkileri. D.E.Ü.İ.I.B.F. Dergisi, Mersin, 21 (1): 127145

Tanık O., 2006. Ekmek üretiminde kalite uygulamaları ve müşteri memnuniyet dinamiklerinin belirlenmesi. Trakya Üniversitesi Fen Bilimleri Enstitüsü (Yayımlanmamış Yüksek Lisans Tezi)Tekirdağ

Taşcı R., Karabak S., Demirtaş R., Şanal T., Pehlivan A., Acar O., Sönmez E., Güneş E., Albayrak M., 2016. Ankara İlinde Buğday Çeşitlerinin Un Sanayisinde Kullanım Durumu, Ekmek Fırınlarının Un Tercihi Ve Ekmekte Tüketici İstekleri Projesi Sonuç Raporu. TAGEM / TEAD /14/ A15/ P02/ 001. Ankara
Özberk F., Karagöz A., Özberk İ. ve Atlı A., 2016. Buğday genetik kaynaklarından yerel ve kültür çeşitlerine; Türkiye'de buğday ve ekmek. Tarla Bitkileri Merkez Araştırma Enstitüsü Dergisi, 25(2):218-233. http://dergipark.gov. tr/tarbitderg/issue/26719/281346

Yılmaz E. ve Özkan S., 2007. Üniversite öğrencilerinin beslenme alışkanlıklarının incelenmesi. Fırat Sağlık Hizmetleri Dergisi, 2 (6): 87-104 